\title{
INTERNATIONAL JOURNAL ON MINORITY AND GROUP RIGHTS
}

Title: Free, prior and informed consent (FPIC) of indigenous peoples before human rights courts and investment law tribunals: Two sides of the same coin?

Author: Dr Belen Olmos Giupponi

Affiliation: Senior Lecturer in EU and International Law - Liverpool Hope University - Hope Park Campus - Liverpool - L16 9JD

Acknowledgements: A previous version of this paper was presented at the Workshop "Prior Consultation and Ethnic Inequalities: A Latin American Comparative Perspective" held at Freie Universitaet Berlin on $8^{\text {th }}$ September 2015. I am grateful to Professor Sergio Costa for his comments on an earlier draft of the paper and to the participants for their feedback.

E-mail: Belen_Olmos_Giupponi@biari.brown.edu 


\title{
Free, Prior and Informed Consent (FPIC) of Indigenous Peoples before Human Rights Courts and International Investment Tribunals: Two Sides of the Same Coin?
}

\begin{abstract}
This article highlights the advances and drawbacks in the recognition and implementation of the right to free, prior and informed consent (FPIC) of indigenous peoples in light of international litigation. Although a certain amount of progress has been achieved, this article demonstrates that a normative gap subsists between the international norms applicable and states' practice. In exploring the topic, the article brings together diverse legal and theoretical components from several areas of law, some of which are not usually regarded as associated with FPIC. In particular, the article considers the interpretation of case law decided by international human rights bodies, regional human rights courts and investment tribunals, critically examining the constraints on their interpretation. The article concludes by analysing the various strategies followed to implement FPIC, and argues for an understanding of FPIC that reaches beyond the human rights arena.
\end{abstract}

\section{Keywords}

Free, prior and informed consent (FPIC); Indigenous peoples' rights; right to consultation; ILO Convention 169; Inter-American Court of Human Rights; African Human Rights System; International investment tribunals

\section{Introduction}

The free, prior and informed consent (FPIC) of indigenous peoples has come under the spotlight after being at the centre of controversy in several cases brought before international human rights bodies, regional human rights courts and international investment tribunals. ${ }^{1}$ In the realm of environmental protection, most of the FPIC cases have dealt with allegations of breach of FPIC concerning the protection of and access to natural resources in indigenous lands.

The article looks into the nature of FPIC under international law. Presently, there are different interpretations of FPIC. Although there is no internationally agreed definition or understanding of the principle or mechanism for implementation, different efforts have been made to reach consensus on a definition. ${ }^{1}$ Scholars have long discussed its nature asserting that

\footnotetext{
${ }^{1}$ For an analysis of the background case law and previous state practice, see P. Tamang, 'An Overview of the Principle of Free, Prior and Informed Consent and Indigenous Peoples in International and Domestic Law and Practices', Workshop on Free, Prior and Informed Consent (New York, 17-19 January 2005), United Nations PFII/2004/WS.2/8, p. 3.
} 


\footnotetext{
${ }^{2}$ See, amongst others: Report of the Special Rapporteur on the rights of indigenous peoples, James Anaya A/HRC/21/47, 6 July 2012, para. 49; Expert Mechanism on the Rights of Indigenous Peoples Final report of the study on indigenous peoples and the right to participate in decision-making, A/HRC/EMRIP/2010/2, 11-15 July 2011, paras. 66-72 and UN Workshop on Indigenous Peoples, Private Sector Natural Resource, Energy and Mining Companies and Human Rights, held in Geneva from 5-7 December 2001, E/CN.4/Sub.2/AC.4/ 2002/3, para. 52.

${ }^{3}$ As of 30 September 2017, ILO Convention 169 has been ratified by 22 states, mainly Latin American states.

${ }^{4}$ V. Mantouvalou, ‘Are Labour Rights Human Rights?’, 3 European Labour Law Journal (2012) p. 151.

5 International Labour Organisation, La aplicación del Convenio Núm. 169 por tribunales nacionales e internacionales en América Latina (ILO, Geneva, 2009).

${ }^{6}$ International Labour Organisation, ILO Convention on Indigenous and Tribal Peoples: A Manual (ILO, Geneva, 2003).

${ }^{7}$ On the proliferation of international tribunals and courts, see K.J. Alter, 'The Multiplication of International Courts and Tribunals after the end of the Cold War', in C. Romano, K.J. Alter and Y. Shany (eds.), The Oxford Handbook of International Adjudication (Oxford University Press, Oxford, 2014), pp. 64-89.

8 A. Xanthaki, Indigenous Rights and United Nations Standards: Self-Determination, Culture and Land (Cambridge University Press, Cambridge 2007).

${ }^{9}$ P. Birnie, A. Boyle and C. Redgwell, International Law and the Environment $\left(3^{\text {rd }}\right.$ Edition, Oxford University Press, Oxford, 2009) p. 272.
} 
tribunals vis-à-vis FPIC where this concerns environmental protection in the application of IHRL and international investment law (IIL).

Against this background, this article scrutinizes how international law addresses the protection of FPIC, in a preventative or reactive manner, focusing on international litigation that stems from cases that involve indigenous peoples' rights. The main contribution to the current debate consists of shedding light on the discussion about the legal nature of FPIC in international law by examining the evolution of case law. The article discusses if FPIC should be considered as an incipient principle or a collateral right with its own distinct core of elements deriving from the various first-order rights upon which it is predicated. Particularised manifestations of FPIC in specific areas of law could be delineated more clearly as emanations of the core elements of this right. This would be regulated within customary international law. The main reason behind this argument is the necessity to observe it in the context of IIL and other specialized fields of international law. This approach to understanding FPIC also creates space for new perspectives on sustainable development as a legal principle intrinsically linked to FPIC since consultation and consent are necessary to undertake major projects affecting indigenous peoples' lands. This article therefore provides a new and original insight into the way FPIC is understood in the human rights realm and by investment tribunals in international litigation. It argues that the current legal framework presents a considerable fragmentation and should be revisited in order to provide a more coherent approach to FPIC.

Through analysing these different cases, legal principles applicable to solve the conflicts that FPIC and its parent rights have with other rights at stake (namely the rights of foreign investors) are identified. Undoubtedly, international investment tribunals and regional human rights courts present distinctive legal features in terms of the scope of their respective jurisdictions, which are then reflected in the approaches taken to FPIC. In the context of international human rights courts and UN treaty bodies jurisprudence, human rights and environmental protection are considered the cornerstones for the safeguard of FPIC. In the context of IEL, sustainable development conceived as an overarching environmental law principle has harnessed the progress in the field of indigenous peoples' rights. ${ }^{10}$

The article also considers how FPIC is perceived within the framework of IIL. Even if investment tribunals often deal with aspects related to sustainable development, which concern the exploitation of indigenous lands and natural resources, they do not operate as international human rights bodies or as environmental courts. Clearly, this leads to fundamentally different standpoints. Whereas for international human rights bodies and regional courts the right to consultation is deep-rooted in the protection of human rights, investment tribunals look at FPIC as a possible interference with investors' rights. What is common to these analyses is the existence of a conflict of rights and the balancing exercise that must be performed by the tribunal or court in question.

The article draws on IHRL and data relating to prior consultations in cases decided by international human rights monitoring bodies, human rights regional courts and investment tribunals regarding indigenous lands and natural resources. By elucidating the common elements that are shared among these very different legal settings, it offers a comprehensive

${ }^{10}$ P. Schwarz, 'Sustainable Development in International Law', 5(1) Non-St. Actors \& Int'l L. (2005) pp. 127152. 
examination of FPIC from a different perspective, contributing to filling a gap in the literature. The analysis provides a route toward the development of a new theoretical approach to FPIC within the framework of sustainable development to reinforce the protection in practice. ${ }^{11}$

Essentially, the study unveils two different approaches to FPIC depending on the theoretical background chosen and legal framework relied upon, taking into consideration the extrapolated interpretation of $\mathrm{C} 169$ (i.e. although not formally being a human rights instrument it is relied upon by international tribunals and bodies to uphold human rights) in order to unravel the different strategies used. Furthermore, the article highlights the gains, shortcomings and disparities between the two different approaches and discusses a solution to bridge them. Finally, the article concludes that a distinctive stance on FPIC arguing in favour of a separate consideration that would avoid confusion with other procedures and would be beneficial to obtaining a fully-fledged protection of FPIC.

In sum, the article casts new light on the issue by considering the nature of FPIC, clarifying the distinctions between consultation and consent, and underscoring the inevitable limitations perceived in the investment arbitral tribunals' approaches to the question.

The article is set out in four parts. First, it provides an account of the general framework concerning indigenous peoples and sustainable development, discussing then the current nature of FPIC under international law. In the second section, selected cases decided by human rights monitoring bodies and investment tribunal are presented and analysed. Section three offers an in-depth discussion of the main issues arising out of the various FPIC-related disputes. The article concludes with some recommendations for the future as a way of moving forward.

\section{Assessing the Current Legal and Theoretical Framework through which FPIC Is Litigated}

From the outset, it is worth clarifying that three different concepts lie at the heart of the discussion: "consultation", "consent", and "free, prior and informed consent". In exercise of the right to consultation and participation, indigenous peoples are entitled to negotiate and participate in decision making in all matters of their concern including land rights. Some scholars submit that this is related to the internal aspect of the right to self-determination. ${ }^{12}$ In turn, the issue of consent arises in particular with regard to land rights. The discussion here revolves around the necessity to consult indigenous peoples and obtain consent in all matters related to the lands in which they live. In Xanthaki's view "it may be too far-reaching to suggest that prior and informed consent is required in all matters affecting indigenous land rights" at present. ${ }^{13}$ FPIC emerges thus as a right in the context of the execution of large development projects that affect the territory of indigenous peoples and involve relocation. This is the specific meaning attributed to FPIC in international legislation and the jurisprudence

\footnotetext{
${ }^{11}$ J. Vanhulst, 'Buen vivir: Emergent Discourse within or beyond Sustainable Development?', 101 Ecological Economics (2014) pp. 54-63.

12 Xanthaki, supra note 8, p. 253.

${ }^{13}$ Ibid., p. 255 in fine.
} 

of international bodies. ${ }^{14}$ To illustrate, the IACtHR has clearly differentiated "consultation" and "consent" in Saramaka stating that "regarding large-scale development or investment projects that would have a major impact within Saramaka territory, the State has a duty, not only to consult with the Saramakas, but also to obtain their free, prior, and informed consent, according to their customs and traditions". 15

Bearing this distinction in mind, the next sub-sections are devoted to analysing the international legal framework and the current theoretical discussions surrounding the nature and implementation of FPIC, respectively.

\subsection{Defining the International Legal Framework Applicable to FPIC}

Essentially, FPIC is regulated through C169 that provides a specific set of norms and through the UN and the American Declarations, although there is a growing body of case law and state practice that may support the thesis that it has achieved customary law status as argued below.

In the framework of the ILO, the implementation of $\mathrm{C} 169$ has contributed to protecting human rights as it contains innovative provisions that other international agreements and domestic legislation have incorporated, particularly in Latin America and the Caribbean. ${ }^{16}$ While adopted within the international labour rights context, the $\mathrm{C} 169$ has become the main tool for the protection of indigenous peoples' rights and its application has gone beyond the mere safeguard of labour rights. ${ }^{17}$ As regards the nature of C169, Mantouvalou explains that "for many decades, the ILO did not explicitly present the documents adopted under its auspices as human rights documents". ${ }^{18}$ However, as Piñero points out, C169 "has gained such a central position in the contemporary defence of indigenous peoples' rights at the international and domestic levels that nobody seems to be concerned any longer with the Convention's (...) origins". ${ }^{19}$

Amongst the indigenous peoples' rights contained therein, Article 16 (2) stands out for its significance since it fleshes out FPIC in these terms: "Where the relocation of these peoples is considered necessary as an exceptional measure, such relocation shall take place only with

\footnotetext{
14 This is the view expressed, for instance, in the following reports: CERD UN Doc. CERD/C/62/CO/2, Consideration of Reports submitted by States Parties under article 9 of the Convention, Concluding observations of the Committee on the Elimination of Racial Discrimination, Ecuador, 2 June 2013, para. 16 and Report of the Special Rapporteur on the rights of indigenous peoples, James Anaya A/HRC/21/47, 6 July 2012, para. 48. Space precludes an exhaustive examination of the legal instruments. For a detailed analysis of the jurisprudence of international bodies, see section 3.

15 Saramaka People v. Suriname, 28 November 2007, I/A Court H.R., Preliminary Objections, Merits, Reparations, and Costs, Judgment, Series C No. 172, paras. 134-137.

${ }^{16}$ ILO Convention No. 169 concerning Indigenous and Tribal Peoples in Independent Countries, signed 27 June 1989, entry into force: 5 September 1991. This Convention replaced Convention 107 (1959) representing a shift from an 'assimilation paradigm' to a new paradigm based on respect for the identity of the indigenous population. C. Rodriguez Garavito, 'Ethnicity.gov: Global Governance, Indigenous Peoples, and the Right to Prior Consultation in Social Minefields', 18:1 Indiana Journal of Global Legal Studies (2010) pp. 1-44. C. Courtis, 'Notes on the Implementation by Latin American Courts of the ILO Convention 169 on Indigenous Peoples' 6:10 Sur International Journal on Human Rights (2009) pp. 53-78.

${ }^{17}$ For a detailed study of the travaux preparatoires, see L. Swepston, The Foundations of Modern International Law on Indigenous and Tribal Peoples, Vol. I (Brill, Leiden, 2015).

${ }^{18}$ Mantouvalou, supra note 4, pp. 4-5.

${ }^{19}$ L. Rodríguez-Piñero, Indigenous Peoples, Postcolonialism, and International Law - The ILO Regime (19191989) (Oxford University Press, Oxford, 2005). In Chapter 9, 'The Language of Rights: Convention No 169 (1989)', pp. 291-331, the author describes this theoretical shift.
} 
their free and informed consent. Where their consent cannot be obtained, such relocation shall take place only following appropriate procedures established by national laws and regulations, including public inquiries where appropriate, which provide the opportunity for effective representation of the peoples concerned". ${ }^{20}$

The ILO norms have paved the way to strengthening the protection of indigenous rights in two essential ways. First, through standard setting they have established common rules and principles for protection at the domestic level, as contracting states have to set up domestic mechanisms and enact appropriate legislation to implement C169. ${ }^{21}$ Second, through monitoring, since states parties to $\mathrm{C} 169$ are under the obligation to report regularly to the ILO bodies on the progress achieved in the implementation of ILO standards. It should be noted nonetheless that the ILO Standards Committee has no specific competence in the protection of human rights, i.e. it cannot order reparation when a violation of human rights arises. ${ }^{22}$

In the absence of a binding instrument in IHRL, declarations consecrating indigenous rights have recognised FPIC at universal and regional level. The 2007 UN Declaration on Indigenous Rights (UNDRIP) in Article 10 proclaims that "[i]ndigenous peoples shall not be forcibly removed from their lands or territories. No relocation shall take place without the free, prior and informed consent of the indigenous peoples concerned". 23

In turn, the 2016 American Declaration on the Rights of Indigenous Peoples (2016 ADRIP) further reinforces the idea that FPIC must be sought on different occasions. Although there is no clear-cut formulation of FPIC it can be inferred from various provisions disseminated across the text. Chiefly, ADRIP proclaims that

[s]tates shall provide redress through effective mechanisms, which may include restitution, developed in conjunction with indigenous peoples, with respect to their cultural, intellectual, religious and spiritual property taken without their free, prior and informed consent or in violation of their laws, traditions and customs. ${ }^{24}$

In addition, indigenous peoples should be consulted in "the adoption and implementation of legislative or administrative measures that may affect them". ${ }^{25}$ FPIC is also necessary for indigenous peoples and individuals to be subject to research programs and biological or medical experimentation. ${ }^{26}$

\footnotetext{
${ }^{20} \mathrm{C} 169$, supra note 16 , Art. 16.

${ }^{21}$ ILO, Understanding the Indigenous and Tribal Peoples Convention, 1989 -No. 169 (International Labour Organization, Geneva, 2013).

${ }^{22}$ Y. Dahan, H. Lerner \& F. Milman-Sivan, 'Shared Responsibility and the International Labour Organization', 34 Mich. J. Int'l L. 675 (2013) pp. 675-743. Report of the Committee set up to examine the representation alleging non-observance by the Government of Peru of the Indigenous and Tribal Peoples Convention, 1989 (No. 169), made under Art. 24 of the ILO Constitution by the International Trade Union Confederation (ITUC), the Trade Union Confederation of the Americas (TUCA) and the Autonomous Workers' Confederation of Peru (CATP). Report of the Committee set up to examine the representation alleging non-observance by the Government of Chile of the Indigenous and Tribal Peoples Convention, 1989 (No. 169), made under Art. 24 of the ILO Constitution by the First Inter-Enterprise Trade Union of Mapuche Bakers of Santiago.

${ }^{23}$ Ibid.

${ }^{24}$ ADRIP, Art. XIII.2.

${ }^{25}$ ADRIP, Art. XXIII.2.

${ }^{26}$ ADRIP, Art. XVIII.3.
} 
Usually, FPIC has been upheld following the recognition of the right to indigenous

\footnotetext{
${ }^{27}$ Sarayaku v. Ecuador - Merits and Costs, I/A Court H.R., Judgment of 27 Jun. 2012, Series C No. 245, para. 159 and paras. 212 to 217.

${ }^{28} \mathrm{M}$. Barelli, 'Free, prior and informed consent in the aftermath of the UN Declaration on the Rights of Indigenous Peoples: developments and challenges ahead', 16:1 The International Journal of Human Rights (2016) pp. 1-24. ${ }^{29}$ J. S. Phillips, "The rights of indigenous peoples under international law", 26:2 Global Bioethics (2015) pp. 120127 , p. 120. See also J. Anaya, International human rights and indigenous peoples (Kluwer Publications, New York, 2009) pp. 79-82, 124, 151.

${ }^{30}$ R. McCorquodale, 'Group Rights' in Moeckli, Shah and Sivakumaran (eds), International Human Rights Law $\left(2^{\text {nd }} E d\right.$, Oxford University Press, Oxford, 2013) pp. 333-355, p. 353.

${ }^{31}$ Sarayaku, supra note 27 , para. 128.

${ }^{32}$ The Court found a violation of the right to communal property pursuant to Art. 21 of the Convention, in relation to the right to cultural identity, in terms of Art. s 1(1) and (2) of the American Convention, para. 232.

${ }^{3}$ S.J. Anaya and S. Puig, 'Mitigating State Sovereignty: The Duty to Consult with Indigenous Peoples', 67 University of Toronto Law Journal (2016) pp. 16-42.
} 
FPIC as this would water it down from an enforceable power to a mere seeking of opinion. As Xanthaki asserts "even if current standards fall short of requiring indigenous consent in all matters related to their land rights, mere consultation is not adequate". ${ }^{34}$

\subsection{Different Theoretical Approaches to Address FPIC}

Because of the centrality of FPIC to the main argument, it is worth discussing the different approaches taken to FPIC. Primarily, the analysis departs from the usual practice of merely focusing on lands rights, as FPIC presents other dimensions. Thus, some preliminary and critical reflections on the nature and definition of FPIC are in order.

From a legal standpoint, the regulation in this area is intricate and made up of ILO norms, IHRL and IEL provisions. ${ }^{35}$ So far, there is no binding legal instrument in IHRL protecting indigenous peoples' right to FPIC. While the 2007 Declaration on Indigenous Rights (UNDRIPs) is of a soft law nature, C169 has turned out to be the main tool at hand for the protection of indigenous peoples' FPIC. Nevertheless, UNDRIP reflects hard law and demonstrates the general consensus on the recognition of FPIC as a human right (or better, a result of various human rights). As Lenzerini indicates UNDRIP "entails an implicit commitment by the international community in favour of indigenous peoples" ${ }^{36}$ From an IEL standpoint, the sustainable development principle also contributes to postulating a general framework for the analysis. Beyond this, from a different perspective, Corporate Social Responsibility approaches play a part in regulation. ${ }^{37}$

As for IHRL, both the International Covenant on Civil and Political Rights (ICCPR), the International Covenant on Economic, Social and Cultural Rights (ICESCR) and the Convention on the Elimination of All Forms of Racial Discrimination (CERD) paved the way for developments that would later lead to the recognition of indigenous rights. ${ }^{38}$ For several decades there had been no tailor-made instruments guaranteeing indigenous rights. To overcome this endemic absence of international law norms specifically designed to protect indigenous peoples' rights, human rights monitoring bodies created standards of protection as discussed in section 3 .

C169 conceives of FPIC as a complete process conducted with the objective of achieving consent, and not a mere source of information. Accordingly, the FPIC should take place when considering legislative or administrative measures ${ }^{39}$; when any consideration is given to indigenous peoples' capacity to alienate their lands or to transmit ownership of them

\footnotetext{
${ }^{34}$ Xanthaki, supra note 8, p. 255.

${ }^{35}$ K. Masaki, 'Recognition or Misrecognition? Pitfalls of Indigenous Peoples Free, Prior, and Informed Consent (FPIC)', in S. Hickey and D Mitlin (eds.), Rights-Based Approaches to Development: Exploring the Potential Pitfalls (Kumarian Press, Sterling, VA, 2009)p. 69.

36 S.J. Anaya, 'Reparations for Neglect of Indigenous Land Rights at the Intersection of Domestic and International Law-The Maya Cases in the Supreme Court of Belize', in F. Lenzerini (ed.) Reparations for Indigenous Peoples: International and Comparative Perspectives (Oxford University Press, Oxford, 2009). See also S.J. Anaya, 'Indigenous Peoples' participatory rights in relation to decisions about natural resource extraction: the more fundamental issue of what rights Indigenous Peoples have in lands and resources', 22 ARIZ. J. INT'L \& COMP. L. 7 (2005) pp. 567-8.

${ }^{37}$ OECD Guidelines for Multinational Enterprises (OECD 2011) and UN Guiding Principles on Business and Human Rights (UN 2011).

${ }^{38}$ CERD adopted and opened for signature and ratification by General Assembly resolution 2106 (XX) of 21 December 1965, entry into force 4 January 1969.

${ }^{39}$ C169, Art. 6.1. a.
} 
outside their own communities. ${ }^{40}$ In light of C169, FPIC is understood as a comprehensive process governed by different principles. ${ }^{41}$ Free and informed consent of indigenous peoples must take place prior to exploration or exploitation of subsurface resources ${ }^{42}$ and prior to relocation and should be obtain for it to be lawful. ${ }^{43}$ The process should be guided by the principle of good faith. The main obligation on the States consists of establishing appropriate channels for effective participation of representative institutions of indigenous or tribal peoples.

The efforts to establish a specific legal framework led to the adoption of the 2007 UNDRIP, which contributes more detail to FPIC: consultation should take place prior to the adoption of legislative and administrative measures and to the approval of projects affecting their lands, territories and resources. UNDRIP regulates the various circumstances in which consultation and consent may take place, with a clear focus on the latter: relocation of the population (Art. 10); activities with impact on culture and intellectual property (Art. 10); adoption and implementation of legislative or administrative measures (Art. 19); exploitation of lands, territories and natural resources (Art. 27); disposal of hazardous waste (Art. 29) and development planning (Art. 30). The obligation to consult indigenous peoples must be interpreted pursuant to Article 7.1 of the Convention, which sets out the rights to decide, to exercise control over their own economic, social and cultural development and to participate "in the formulation, implementation of plans and programmes for national and regional development which may affect them directly'. ${ }^{44}$

The scope of the protection afforded to indigenous communities comprises the right to be consulted about projects that may affect their land rights and the right to reparation in the case of dispossession and invasion of indigenous lands. The protection of indigenous lands under IHRL is rooted on the right to property, the respect for their cultural identity and entwined with the protection of the environment. The applicable legal framework to settle disputes $^{45}$ (mainly the C169 and other human rights instruments) is ascertained through a caseby-case analysis to determine if the state in question has ratified or acceded to main international human rights treaties. While FPIC has been recognised as a right, several controversial issues persist. Among them, there is the safeguarding of land rights and the protection of FPIC in cases of large projects involving natural resources that would affect indigenous lands.

Another way to consider FPIC is through the IEL lens. ${ }^{46}$ Although there is no direct regulation of FPIC in the realm of IEL, sustainable development and indigenous peoples' rights are closely interconnected, as the latter encompass rights with a clear environmental dimension,

\footnotetext{
40 C169, Art. 17.

${ }^{41}$ ILO, Understanding the Indigenous and Tribal Peoples Convention, 189 (United Nations, Geneva, 2013).

${ }^{42}$ C169, Art. 15.2.

${ }^{43}$ C169, Art. 16.

${ }^{44}$ Ibid.

${ }^{45}$ D. Lea, Property Rights, Indigenous People and the Developing World (Brill, Leiden, 2008), p. 51.

46 L. Rodríguez-Piñero Royo, 'Las agresiones del desarrollo: pueblos indígenas, normas internacionales e industrias extractivas', 11 Relaciones internacionales: Revista académica cuatrimestral de publicación electrónica (2009) pp. 43-78.
} 
such as land rights. ${ }^{47}$ However, IEL norms initially lacked a rights-based approach. This perspective appeared later, and only because of a shift in IEL to a more protective approach.

This early lack of a rights-based approach is observed in the formulation of sustainable development, a fundamental environmental principle proclaimed in the 1992 Rio Conference. On the face of it, it appears, among other aims, to highlight a connection between indigenous peoples' rights and sustainable development. ${ }^{48}$ The Declaration of the UN Conference on Environment and Development, Principle 22, affirms that:

indigenous peoples and their communities (...) have a vital role in environmental management and development because of their knowledge and traditional practices. States should recognize and duly support their identity, culture and interests and enable their effective participation in the achievement of sustainable development. ${ }^{49}$

However, the language of rights is not present in this formulation. As Shelton correctly states in her critique, "Principle 22 is not (...) right-based and ignores both historical injustices and the insistent demands of indigenous peoples for recognition of their land rights and selfdetermination". 50

Traditionally, "key instruments in the sphere of international environmental law do not refer directly to FPIC". ${ }^{51}$ More recently, IEL instruments recognise land rights and indigenous peoples' important contribution to sustainable development, and call for the protection of their traditional cultures and lifestyles. The 2012 Rio Declaration stresses "the participation of indigenous peoples in the achievement of sustainable development and the importance of the UNDRIP in the context of global, regional, national and subnational implementation of sustainable development strategies". 52

In this evolution, Barelli links FPIC to public participation in environmental decision making affecting indigenous territories which reveals that a "trend has become even more significant in respect of indigenous peoples in view of their special cultural attachment to ancestral lands". ${ }^{53}$ Dupuy and Vinuales point out that under IEL indigenous peoples a variation of FPIC "appears in the biodiversity regime" as it requires "approval as a condition for the utilisation of indigenous traditional knowledge". 54

\footnotetext{
${ }^{47}$ B. Kingsbury, 'Indigenous Peoples and the Environment', in D. K. Anton, D. L. Shelton (eds.), Environmental Protection and Human Rights (Cambridge University Press, Cambridge, 2011) p. 545. C. Chi Ngang, 'Indigenous Peoples' Right to Sustainable Development and the Green Economy Agenda', 44(4) Africa Insight (2015) pp. 3146.

${ }^{48}$ U.N. Conference on Environment and Development, U.N. Doc. A/.CONF,151/26 (1992), Agenda 21, Ch. 26.1. D. Freestone, 'The Road from Rio: International Environmental Law after the Earth Summit', 6:2 J Environmental Law (1994) pp. 193-218. J. Viñuales, The Rio Declaration on Environment and Development: A Commentary (Oxford University Press, Oxford, 2016).

${ }^{49}$ U.N. Doc. A/CONF.151/26 (1992), UN 1992 Rio Conference.

${ }^{50}$ D. Shelton, 'Principle 22' in J. Viñules (ed.), The Rio Declaration on Environment and Development: A Commentary (Oxford University Press, Oxford, 2016) pp. 541-556, p. 544.

${ }^{51}$ Barelli, supra note 28.

${ }^{52}$ UN 2012 Rio + Conference, Final Document, A/RES/66/288 - The Future We Want, para. 49.

${ }^{53}$ Barelli, supra note 28, p. 3.

${ }^{54}$ P.M. Dupuy and J. Viñuales, International Environmental Law (Cambridge University Press, Cambridge, 2015) p. 67.
} 
Environmental conflicts are often associated with non-compliance with FPIC. Indeed, various contentious cases have demonstrated the difficulties faced in the implementation of FPIC. Extractive industries constitute an area of potential conflict, where it is difficult to prevent harmful environmental effects to indigenous communities. ${ }^{55}$

Both the principle of sustainable development and FPIC may play a significant role in the protection of indigenous rights, helping to prevent environmental harm to indigenous communities. ${ }^{56}$ At the same time, FPIC highlights the need for at least a minimum condition of a mechanism for indigenous peoples to participate in processes involving questions where their interests are directly affected (such as development projects), and in environmental decision-making, which is articulated in different ways. ${ }^{57}$ The Cartagena Protocol on Biosafety (2000) does not institute a fully-realised FPIC but it does draw upon a softer formulation based on consultation as a mechanism to channel the participation of indigenous peoples in matters that directly affect them; such as the transboundary movement, transit, handling, and use of all living organisms and to block potentially harmful activities. ${ }^{58}$

An added difficulty arises in the implementation of norms, as there is often a confusion between the practice of carrying out an EIA on the part of the state and the guarantee of the effective exercise of FPIC. There is a widely held position amongst states when confronted with FPIC that argues that an EIA counts as consultation, even if legally these are two different procedures. The EIA is conducted by the state and it should include the participation of affected individuals and groups. However, this is not equivalent to consultation aimed at obtaining consent. A strategy that would enable parties to disentangle this confusion would be to stress the separation between the EIA and the exercise of FPIC during the procedure of authorisation of a specific project.

Another crucial aspect concerns environmental justice, understood as the access to a fair process of law and comprising a transnational dimension provided by environmental protection laws. This requires an exhaustive prior monitoring of the project through an appropriate EIA, an informed and non-coercive FPIC process and the granting by the State of procedural rights. International litigation is scattered and often takes place before various international bodies. Relevant case law on FPIC has mainly emanated from international human rights bodies, but also from investment tribunals. What is needed for development projects is a body or institution providing expert oversight across the various hard and soft areas of law that may - at differing times - govern this decision-making.

Yet another relevant source of law in this field is the nascent law concerning corporate social responsibility (LCSR). ${ }^{59}$ One of the peculiarities of the current context is the longestablished and increasingly dominant role of corporations in international trade and

\footnotetext{
${ }^{55}$ D. Lertzman and H. Vredenburg, 'Indigenous Peoples, Resource Extraction and Sustainable Development: An Ethical Approach', 56 (3) Journal of Business Ethics (2005)pp. 239-254.

${ }^{56}$ Dupuy and Viñuales, supra note 54, p. 66. As the authors emphasise, prior informed consent has different meanings in IEL.

57 T. Ward, 'The Right to Free, Prior, and Informed Consent: Indigenous Peoples' Participation Rights within International Law', 10:2 Nw. J. Int'l Hum. Rts. (2011) pp. 54-84.

${ }^{58}$ The Cartagena Protocol on Biosafety to the Convention on Biological Diversity, adopted on 29 January 2000, entry into force 11 September 2003.

${ }^{59}$ Human Rights Council, Report of the Special Rapporteur on the rights of indigenous peoples, James Anaya: Extractive industries and indigenous peoples, UN Doc. A/ HRC/24/41 (1 July 2013), para. 32.
} 
investment. The problems are acute where multinational corporations operate in the developing world and, as Lea reports, are faced with group self-determination and customary land tenure and communal holdings, which could create tensions between the different stakes. ${ }^{60}$

Another pervasive question regards the responsibility and liability of non-state actors (namely corporations) vis-à-vis the implementation of FPIC. The international law framework concerning LCSR is still embryonic, consisting of several norms namely the Ruggie Principles and the OECD Guidelines on Multinational Businesses, although there is a myriad of several instruments all anchored in IHRL. ${ }^{61}$ Although proposals for the adoption of a treaty have made considerable progress, up to the present the applicable law is namely of soft law nature. ${ }^{62}$

Against this backdrop, the contentious issue regards the responsibility of corporations to respect FPIC. States are always ultimately responsible for ensuring that human rights are observed within their jurisdiction, including FPIC. However, under the framework of accountability of non-state corporate actors to protect, respect and remedy, corporations should bear responsibility to respect consultation and FPIC by exercising due diligence "so as to avoid becoming complicit in human rights violations committed by host governments" ${ }^{63}$ As emphasized by Special Rapporteur Anaya, due diligence includes "ensuring that corporate behaviour does not infringe or contribute to the infringement of the rights of indigenous peoples (...) regardless of the reach of domestic laws" ${ }^{64}$ Corporations shall "adhere to the principle of gaining consent 'prior', and seek consent before commencing specified stages of operations". ${ }^{65}$

The UNHRC has encouraged the use of the Guiding Principles to promote 'corporate responsibility to respect human rights in relation to indigenous peoples and business activities in alignment with other relevant standards, including the UNDRIP' ${ }^{66}$

In sum, the legal framework concerning both FPIC and related principles is fragmented and comprises a variety of very different provisions. At the heart of the discussions, there is the nature of FPIC understood as an independent self-standing legal principle to be applied for the more effective assertion of rights such as the right to communal property, but also as capable of being elevated to a fully realised second-order human right in itself.

\section{FPIC in the Case Law of International Human Rights Treaty Bodies, Regional Human Rights Bodies and International Investment Tribunals}

\footnotetext{
${ }^{60}$ Lea, supra note 45 , pp. 31 and 87.

${ }^{61}$ UN-REDD, Programme Guidelines on Free, Prior and Informed Consent (2013); United Nations, Reports of the Working Group on the issue of human rights and transnational corporations and other business enterprises (2013).

${ }^{62}$ A. Ramasastry and D. Cassel, 'White Paper: Options for a Treaty on Business and Human Rights', 6:1 Notre Dame Journal of International \& Comparative Law (2016) pp. 1-50.

${ }^{63}$ Human Rights Council, Report of the Special Rapporteur on the human rights obligations related to environmentally sound management and disposal of hazardous substances and waste, UN Doc. A/HRC/21/48 (2 July 2012) para. 70(d).

${ }^{64}$ Human Rights Council, Report of the Special Rapporteur on the rights of indigenous peoples, James Anaya, UN Doc.A/HRC/21/47 (6 July 2012) para. 61.

${ }^{65}$ A. K. Lehr and G.A. Smith, Implementing a Corporate Free, Prior, and Informed Consent Policy: Benefits and Challenges (Foley Hoag LLP, Boston/Washington, D.C., 2010) p. 8.

${ }^{66}$ Human Rights Council, Report of the Working Group on the issue of human rights and transnational corporations and other business enterprises, UN Doc. A/HRC/23/32 (14 March 2013) para. 53
} 
The difficulties arising out of the implementation of PFIC are better appreciated in light of international case law. Most of the cases revolve around the tensions or conflicts between two different kinds of property: on the one hand, the foreign investor's private property and, on the other hand, indigenous property. Human rights monitoring bodies take a broader approach as they consider right to property and land rights aligned with the respect of cultural rights. In contrast, arbitral tribunals focus on the protection of investors' rights overlooking the protection of indigenous rights.

In cases heard before international human rights treaty bodies, FPIC has been protected as a human right stemming from the protection of other rights, namely property rights over land and cultural diversity rights. Conversely, under IIL, operating as a highly specialised regimen, human rights and FPIC are considered as non-related aspects of investment protection, only receiving marginal attention. Thus, international investment tribunals, in principle, concentrate on the protection of investors' rights. In most of the cases, the violation of land rights is coupled with socio-economic inequality. ${ }^{67}$

Beyond the human rights realm, FPIC norms are relied upon only occasionally in other international fora, and scarcely in international investment practice. International investment law is seen as a self-contained regime and arbitrators are frequently reluctant to open up to the influence of external sources. Unlike international human rights bodies, investment tribunals are made up of arbitrators who often come from private law practice (commercial arbitration) and from public international law (academic roles). ${ }^{68}$ On the other hand, the existence of a global public interest including international environmental law principles and human rights issues has led to the introduction of some considerations of FPIC issues. ${ }^{69}$

\subsection{Cases before International and Regional Human Rights Monitoring Bodies}

FPIC has been protected in the different human right systems created both at the UN level and on a regional level. The case law emanating from these systems has contributed to establishing customary international norms to guarantee FPIC.

At the UN level, the Human Rights Council, the Expert Mechanism on the Rights of Indigenous Peoples (EMRIP) and various rapporteurs have dealt with FPIC. ${ }^{70}$ The UN Special Rapporteur on Indigenous Peoples has issued various reports concerning FPIC. ${ }^{71}$ In turn, the specialised UN monitoring mechanism has played a significant role in setting standards. In the framework of ILO, the Tripartite Committee has also contributed to protecting FPIC. The Human Rights Committee (HRC) operates within the legal framework of the International Covenant on Civil and Political Rights, one of its tasks being to focus on Articles 1 and 27, to protect ethnic, religious or linguistic minorities, putting the obligation on the states to ensure

\footnotetext{
${ }^{67}$ ECLAC, Guaranteeing indigenous people's rights in Latin America. Progress in the past decade and remaining challenges (Santiago 2014) p. 5.

${ }^{68}$ J. Pauwelyn, 'The Rule of Law without the Rule of Lawyers? Why Investment Arbitrators are from Mars, Trade Adjudicators are from Venus', 109 A.J.I.L. (2015) p. 761.

69 A. Kulick, Global Public Interest in International Investment Law (Cambridge University Press, Cambridge, 2013) pp. 225-271.

${ }^{70}$ The Expert Mechanism on the Rights of Indigenous Peoples (EMRIP) was established by the Human Rights Council, the UN's main human rights body, in 2007 under Resolution 6/36 as a subsidiary body of the Council.

${ }^{71}$ See Human Rights Council, Report of the Special Rapporteur on the rights of indigenous peoples, James Anaya: Extractive industries and indigenous peoples, UN Doc. A/ HRC/24/41 (1 July 2013) para. 32.
} 
that persons belonging to such minorities "shall not be denied the right, in community with the other members of their group, to enjoy their own culture, to profess and practice their own religion, and to use their own language", ${ }^{72}$

Furthermore, the HRC General Comment $N^{\circ}$ 23(50) (Article 27) when referring to natural resources clearly states that

[c]ulture manifests itself in many forms, including a particular way of life associated with the use of land resources (...) [t] he enjoyment of these rights may require positive measures of protection and measures to ensure the effective participation of members of minority communities in decisions which affect them. ${ }^{73}$

The adoption of UNDRIP signified a turning point in this protection because it draws together specific rights in a systematic manner. Specifically concerning FPIC in Poma-Poma, the HRC recalled that "participation in the decision-making process must be effective, which requires not mere consultation but the free, prior and informed consent of the members of the community". ${ }^{74}$

In turn, the Committee on Economic, Social and Cultural Rights (CESCR) has referred to FPIC in General Comment No. 21, calling states on to "respect the principle of free, prior, and informed consent of indigenous peoples in all matters covered by their specific rights" and specifically to "obtain their free and informed prior consent when the preservation of their cultural resources, especially those associated with their way of life and cultural expression, are at risk" ${ }^{75}$

A brief reference to the work of the Committee on the Elimination of Racial Discrimination (CERD) and the principle of non-discrimination is in order. According to its 1997 General Recommendation No 23 on indigenous people, states must ensure that no decisions relating directly to indigenous peoples are to be taken without their informed consent. ${ }^{76}$ CERD has constantly defend the right to consult of indigenous peoples as shown in earlier cases. ${ }^{77}$ In recent cases, CERD has emphasised the obligation of States to obtain in good faith free, prior and informed consent of indigenous peoples. ${ }^{78}$

On the regional level, the case law on FPIC issued by regional human rights monitoring bodies has emerged in the Inter-American Human Rights System and in the African Human Rights System. Along with regional human rights instruments, both the Inter-American Commission and the Court in cases concerning indigenous property and resettlement, as well

72 See Human Rights Committee, L.E. Länsmann v. Finland, Communication N $^{\text {o }}$ 671/1995, CCPR/C/58/D/671/1995; Ominayak Chief of the Lubicon Lake Band of Cree v. Canada, Communication $\mathrm{N}^{\circ}$ $167 / 1984$.

${ }^{73}$ Human Rights Council, CCPR General Comment No. 23: Art. 27 (Rights of Minorities), 8 April 1994, CCPR/C/21/Rev.1/Add.5, para. 7.

${ }^{74}$ Human Rights Council, Communication No. 1457/2006, Ángela Poma Poma v. Peru, 27 March 2009U.N. Doc. CCPR/C/95/D/1457/2006.

${ }^{75}$ CESCR, General Comment No. 21, 21 December 2009, E/C.12/GC/21.

76 CERD, General Recommendation 23, Rights of indigenous peoples (Fifty-first session, 1997), U.N. Doc. A/52/18, annex V at 122 (1997).

77 Concluding observations Australia CERD/C/56/Misc.42/rev.3. 24/03/2000 para. 9 and Botswana UN Doc.A/57/18, 23/08/2002, para. 304.

${ }^{78}$ CERD, Concluding observations (CERD/C/USA/CO/6) March 2008. 
as in controversies related to conflicts between investors' rights and indigenous peoples' rights have frequently applied C169. Of particular interest are the cases that involve FPIC vis-à-vis the exploitation of natural resources such as oil concessions or mining activities. Overall, the underlying argument is that indigenous communities should have the right to control (and consent over) the utilisation of such natural resources, including the territories where these are situated and that any harmful effects such as pollution should be redressed to restore the situation to the status quo ante.

Together with respect for the cultural identity of communities, the interconnection between FPIC environmental rights protection, relevant for this article's purpose, has been made evident in some cases before regional human rights bodies. Therefore, the focus is thus placed on the conflict between FPIC and investors' rights and the conception of sustainable development as upheld by them Regional monitoring bodies will argue it that, in the application of IHRL (and C169), there is an environmental rights dimension that demonstrates a connection between indigenous peoples' rights and the environment. The discussion that follows will show how this connection is based upon and intertwined with the right to life, the right to property and cultural rights.

The discussion will focus on three key aspects of the case law. First, the text examines the Inter-American Commission (IACHR's or 'the Commission') case law concerning FPIC and natural resources. Second, the analysis will set out the Inter American Court of Human Rights (IACtHR or 'the Court') role. Third, a comparative perspective taking into consideration the African Human Rights System is presented.

Turning first to the Inter-American Human Rights System: both bodies (the InterAmerican Commission and the Court) have addressed FPIC and indigenous peoples' rights to their traditional knowledge and practices in the area of environmental management and conservation. The application of FPIC norms in the Inter-American Human Rights System mostly deals with forced displacements, harmful effects caused by extractive industries and investment projects and the protection of indigenous peoples' land rights and water rights. International legal scholarship has mainly focused on the Inter-American Court of Human Rights (IACtHR) jurisprudence concerning indigenous rights, and the Commission's activity has received less attention. The Commission holds the key to an effective protection of FPIC as the only body before which petitioners have legal standing; it retains a first-hand knowledge of the cases; and it is in charge of requesting precautionary measures to protect rights and avoid the worsening of human rights violations.

From the beginning, the IACHR, as the specialised organ of the Organisation of American States, has led the way in the protection of indigenous peoples' rights, for a series of reasons. First, the scope of its protection is broader as the Commission can investigate alleged violations of the American Declaration, extending its actions to cover all OAS member states: even to non-signatories of the Convention. Second, the IACHR has also fostered the development of Inter-American law through the Rapporteurship on the Rights of Indigenous Peoples, which was created to fulfil that specific goal. Third and as previously indicated, individuals and groups only have locus standis before the Commission; only states and the Commission can appear before the Court. Fourth, the Commission has often requested precautionary and provisional measures in cases relating to indigenous property and, in 
particular, those reflecting a conflict between investors' rights and the protection of the former. $^{79}$

A wide array of instruments cited to substantiate the petitions filed before the Commission could be observed. In addition to the UNDRIP, the previous draft of the American Declaration on the Rights of Indigenous Peoples is often alluded to in the text as regards developments contributing to legal protection of statuses, which underpin FPIC. Additionally, petitioners have quoted other international instruments adopted within other regional organisations to make claims concerning the protection of land and cultural rights, such as the Charter of the Civil Society of the Caribbean Community, which stipulates that "[s]tates recognize the contribution of the indigenous peoples to the development process and undertake to continue to protect their historical rights and respect the culture and way of life of these peoples". 80

In terms of FPIC, one particular aspect that should be underlined throughout the Commission case law refers to the linkages between the right to consultation, FPIC and the protection of the environment. In light of various cases heard before the Commission, one may observe how FPIC is effectively safeguarded. Space precludes the possibility to provide a detailed account of all the different cases, but three key ones should help to understand how FPIC protection operates.

In Marlin mining project, a case concerning Guatemala, the IACHR ordered the defendant state to suspend the exploitation of a gold mine that it had granted to a multinational firm, Goldcorp, as a precautionary measure to safeguard Maya People's rights. ${ }^{81}$ In its response, Guatemala alleged that the consultation had taken place during the EIA process. In the final report on the case, the Commission clarified that "consultations must be meaningful and they should take place with the aim of obtaining consent". ${ }^{82}$ Referring to environmental rights and, in particular, sustainable development (a legal principle noted above to be intrinsically linked to FPIC since consultation and consent are necessary to undertake major projects concerning indigenous peoples), the Commission derived specific obligations upon a government emanating from the right to a general satisfactory environment. This translates into the State's obligation "to take reasonable and other measures to prevent pollution and ecological degradation, to promote conservation, and to secure an ecologically sustainable development and use of natural resources". ${ }^{83}$

In Huenteao Beroiza, a case relating to the construction of a dam in Chile, the Commission was confronted with a conflict of rights between investors and indigenous

\footnotetext{
${ }^{79}$ Case 7664 (Nicaragua), IACHR., Report on the Situation of a Segment of the Nicaraguan Population of Miskito Origin, OEA/Ser.L/V/II.62, doc. 10 rev 3 (1983) p. 76-78, 81; Case 7615 (Brazil), IACHR, OEA/Ser.L/V.II.66, doc. 10, rev.1, (1985) pp. 24, 31; IACHR, Report on the Situation of Human Rights in Ecuador, OEA/Ser.L/V/II.96 Doc. 10 rev. 1 (24 April 1997), at 103-4.

${ }^{80}$ Maya indigenous community of the Toledo District v. Belize, Case 12.053, Petitioners' application August 7 , 1998, IACHR, p. 30, paras. 102-108. The Charter was adopted by the Heads of government of the State members of the Caribbean Community on February 19, 1997.

${ }^{81}$ Communities of the Sipakepense and Mam Mayan People of the Municipalities of Sipacapa and San Miguel Ixtahuacán Guatemala, 20 May 2010, Precautionary Measures, IACHR, Order of the Comm'n, No. PM 260-07. 82 Report on Admissibility Communities of the Sipakepense and Mam Mayan People of The Municipalities of Sipacapa and San Miguel Ixtahuacán Guatemala, 3 April 2014, IACHR, Report No. 20/14, Petition 1566-07. ${ }^{83}$ Ibid, para. 52.
} 
communities that finally resulted in an amicable settlement. ${ }^{84}$ After conducting the EIA for the project, the National Environment Commission (CONAMA in Spanish) approved the construction of the hydroelectric plant: however, the Indigenous Peoples Act (Law 19.253) required that the relocation of the indigenous population should only proceed with the consent and willingness of those affected. The IACHR detailed the requirements imposed by the Indigenous Peoples Act to the relocation: it stated that the swapping of lands should be authorised by the relevant State institution (the National Corporation for Indigenous Development); this could only be done for another property that satisfied the indigenous person involved; and also the original property would change the initial qualification as indigenous land, a classification that would be transferred to the property allocated in exchange. ${ }^{85}$

In Maya Indigenous Communities of the Toledo District, the Commission dealt with a complaint that Belize had violated several articles of the American Declaration in respect of lands traditionally used and occupied by the Maya people. ${ }^{86}$ The state's violation had taken place by granting logging and oil concessions and failing to adequately protect those lands; failing to recognize and secure the territorial rights of the Maya people and failing to afford the Maya people judicial protection of their rights and interests in the lands due to delays in court proceedings instituted. According to the petitioners, the State's contraventions affected negatively the natural environment upon which the Maya people depend for subsistence, threatening the Maya people and their culture, and risking inflicting future damage. ${ }^{87}$

If the Commission heralded a new era in the protection of indigenous peoples' rights in the Americas, the Court has contributed a consistent judicial doctrine on the protection of indigenous peoples in various cases brought before it. Over the years, the Court has elaborated its case law based on the application of $\mathrm{C} 169$ and Article 21 of the Convention that protects the right to property, following the pro-homine principle, in accordance with Article 31.3.c of VCLT. Along these lines, the Court has protected indigenous peoples' rights to property and cultural identity. Interestingly, the IACtHR, pursuant to Articles 1.1 and 29.b of ACHR, has also applied other treaties to strengthen the protection of FPIC, such as the ICCPR. In general, the Court has anchored its jurisprudence in the right to indigenous communal property, right to consultation and cultural identity and the rights to judicial guarantees. ${ }^{88}$

The first cases, considered pivotal to the protection of indigenous peoples' rights, are Aleoeboetoe regarding reparations for violation of tribal people in Suriname (settled by acknowledgment of the State) in light of Art. 63.1 of the ACHR and Awas Tingni concerning indigenous property rights. ${ }^{89}$ These laid down some general foundations such as the obligation of states to protect indigenous communal property and cultural rights and the 'evolutionary interpretation' of human rights treaties which "are live instruments whose interpretation must

\footnotetext{
${ }^{84}$ Friendly Settlement, Mercedes Julia Huenteao Beroiza et al. v. Chile, 11 March, 2004, IACHR, Report n. 30/04, Petition 4617/02.

${ }^{85} \mathrm{Ibid}$.

${ }^{86}$ Maya Indigenous Community of the Toledo District v. Belize, 12 October 2004, IACHR, Case 12.053, Report No. 40/04, Inter-Am. C.H.R., OEA/Ser.L/V/II.122 Doc. 5 rev. 1, para. 727. See Arts. I, II, III, VI, XI, XVIII, XX and XXIII of the American Convention.

${ }^{87}$ Ibid, para. $197(1)$.

${ }^{88}$ Sarayaku, supra note 27 , para. 112.

89 B. Olmos Giupponi, 'La protección de los derechos de los afrodescendientes en el espacio eurolatinoamericano', 1:I REIB: Revista Electrónica Iberoamericana (2007) pp. 75-88.
} 
adapt to the evolution of the times and, specifically, to current living conditions". ${ }^{90}$ After those cases, IACtHR has relied on the previous dicta to uphold indigenous peoples' rights. One can notice an evolution in the jurisprudence to nail down specific issues among which FPIC occupies a central position. In the IACtHR's case law, Awas Tigni is a landmark case regarding indigenous communities as argued; Sarayaku constitutes the most significant contribution with regard to FPIC as argued below.

The Court has supported its arguments by reference to the practice of the UN Human Rights Committee on the interpretation of Article 27 of the ICCPR: the IACtHR has established that in terms of the exploitation of natural resources in indigenous communal property, indigenous peoples should be consulted, thus upholding FPIC. In ascertaining FPIC, the Court has also referred to environmental protection and made use of previous case law.

Evidently, FPIC is intrinsically linked to the right to property as protected in Article 21 of the Convention, a paramount right in the case law relating to indigenous property, which also encompasses an environmental dimension as demonstrated in the different cases. ${ }^{91}$ Also, and more importantly, the links of indigenous peoples with their traditional territories and the natural resources are embodied in the overall protection of their culture..$^{92}$

The protection of FPIC by the IACtHR has unfolded in successive stages, with different connotations at each stage. Indeed, there are different turning points concerning interpretative tools, substantive and procedural aspects in the Court's jurisprudence.

As regards interpretation, the main controversial issue that arose is the application of the principles enshrined in $\mathrm{C} 169$ to states that have not ratified it. The Court was faced with such a predicament in Aloeboetoe et al v. Suriname, where it set out the interpretation criterion:

The I.L.O. Convention $\mathrm{N}^{\mathrm{o}} 169$ concerning Indigenous and Tribal Peoples in Independent Countries (1989) has not been accepted by Suriname. Furthermore, under international law there is no conventional or customary rule that would indicate who the successors of a person are. Consequently, the Court has no alternative but to apply general principles of law (Art. 38(1)(c) of the Statute of the International Court of Justice). ${ }^{93}$

This criterion was re-affirmed in Saramaka People:

Suriname's domestic legislation does not recognize a right to communal property of members of its tribal communities, and it has not ratified C169. Nevertheless, Suriname

\footnotetext{
${ }^{90}$ Mayagna (Sumo) Awas Tingni Community v. Nicaragua, Merits, Reparations, and Costs, 31 August 2001, I/A Court H.R., Judgment, para. 146.

${ }^{91}$ G. Citroni and K. Quintana Osuna, 'Reparations for Indigenous Peoples in the Case Law of the Inter-American Court of Human Rights' in Lenzerini, supra note 36, p. 319.

${ }^{92}$ See also Awas Tingni, supra note 90, para. 149; Case of the Sawhoyamaxa Indigenous Community v. Paraguay, Merits, Reparations, and Costs, I/A Court H.R., 29 March 2006, Judgment, Series C No. 146, para. 131 and Comunidad Indígena Sarayaku (Spanish only), 17 June 2005, I/A Court H.R., Provisional Measures, para. 9.

${ }^{93}$ Aloeboetoe et al v. Suriname, 4 December 1991, I/A Court H.R., Judgment, Series C No. 11, para. 61.
} 
has ratified both the International Covenant on Civil and Political Rights as well as the

In Yakye Axa Community, the Court held that, to interpret Article 21 and other provisions of the ACHR, it was "useful and appropriate to resort to other international treaties, aside from the American Convention, such as C169". ${ }^{95}$ In this case, the Court has asserted the relevance of C169 in defining traditional property in the framework of consultation.

In terms of substantive provisions, in Sawhoyamaxa Community there was a latent controversy between indigenous property and a foreign investment made under a Bilateral Investment Treaty (BIT) between Germany and Paraguay. ${ }^{96}$ As part of its pleadings, the respondent state alleged that the supposedly indigenous lands were legally considered to be and registered as private property. ${ }^{97}$ The Court observed:

that the enforcement of bilateral commercial treaties (...) should always be compatible with the American Convention, which is a multilateral treaty on human rights that stands in a class of its own and that generates rights for individual human beings and does not depend entirely on reciprocity among States. ${ }^{98}$

The Court then looked at the conflict between the BIT and the state's obligations under the ACHR, to advocate a higher hierarchy of the Convention, i.e. that it takes precedence over the BIT based on different elements: (1) the Convention "is a multilateral treaty on human rights"; (2) it "stands in a class of its own"; (3) it "generates rights for individual human beings"; and (4) it "does not depend entirely on reciprocity among States". 99

In Community Yakye Axa ${ }^{100}$, the Court asserted the obligation of the state to protect indigenous peoples' rights and resorted to expert witnesses to determine the cultural and environmental context. ${ }^{101}$ The Court affirmed that Article 21 places the state under the obligation to acquire those lands and transfer them to the Community free of cost, after making sure that said lands are the traditional habitat of the indigenous nation. The Court went on to indicate that " $[\mathrm{t}]$ he traditional habitat, in addition to being the traditional place of settlement of the indigenous people, must have ecological and environmental conditions that are in accordance with the community's traditional manner of life". ${ }^{102}$ The Court examined the question of conflicts between private property and indigenous property:

\footnotetext{
${ }^{94}$ Saramaka, supra note 15, para. 93. L. Brunner, 'The Rise of Peoples' Rights in the Americas: The Saramaka People Decision of the Inter-American Court of Human Rights', 7 Chinese J. Int'l L. 699, 708 (2008) pp. 99-711. ${ }^{95}$ Yakye Axa Indigenous Community v. Paraguay, 17 June 2005, I/A Court H.R., Judgment, Series C No. 125.

${ }^{96}$ Sawhoyamaxa Indigenous Community, supra note 92, para. 106.

${ }^{97}$ Ibid.

${ }^{98} \mathrm{Ibid}$

${ }^{99}$ Ibid., para. 212.

${ }^{100}$ Ibid.

${ }^{101}$ Ibid., para. 217.

${ }^{102}$ For instance, the statement by the expert witness, illustrated the manner in which indigenous peoples perceived foreign investors as 'lords' who caused 'personality disorders or illnesses, as well as environmental catastrophes or difficult situations', ibid. para. 38.d.
} 
When they apply these standards to clashes between private property and claims for ancestral property by the members of indigenous communities, the States must assess, on a case by case basis, the restrictions that would result from recognizing one right over the other. Thus, for example, the States must take into account that indigenous territorial rights encompass a broader and different concept that relates to the collective right to survival as an organized people, with control over their habitat as a necessary condition for reproduction of their culture, for their own development and to carry out their life aspirations. Property of the land ensures that the members of the indigenous communities preserve their cultural heritage. ${ }^{103}$

The considerations regarding prior informed consent are reinforced in another case decided at around the same time: this was Moiwana Community, ${ }^{104}$ a complaint relating to the alleged massacre of members of indigenous communities and delimitation of property with consultation. ${ }^{105}$

In another landmark case, Saramaka People v. Suriname, the Court developed a test that throws light in the conflict between investors' rights and indigenous peoples' right. ${ }^{106}$ In Saramaka, the controversy arose because of logging and mining concessions for the exploration and extraction of certain natural resources located within Saramaka territory granted without their consent. The Court set out a 'test' which should be applied when assessing a development project in indigenous people's lands that affects traditionally used natural resources. ${ }^{107}$ This 'safeguards test' (as referred to by the Court) consists of different steps. ${ }^{108}$ First, there must be effective consultation with indigenous peoples (in accordance with their customs and traditions) concerning any development, investment, exploration or extraction plan ('development or investment plan') that may affect their property. ${ }^{109}$ If it is a large scale project that could impact the survival of a people full consent is required. Second, there must be a tangible benefit for the indigenous peoples: the State should guarantee a 'reasonable benefit from any such plan within their territory'. ${ }^{110}$ Third, the State must ensure that no concession will be issued within indigenous territory 'unless and until independent and technically capable entities, with the State's supervision, perform a prior environmental and social impact assessment ${ }^{\text {'. }}{ }^{111}$ Additionally, the right to judicial protection enshrined in Article 25 of the American Convention should be protected, i.e. there needs to be access to judicial review of the decisions adopted. In that, specific case the state had failed to adopt such measures, to the detriment of the Saramaka people. ${ }^{112}$ In accordance with this Article, and the Court's jurisprudence, exceptionally the state may restrict, under certain circumstances, the

\footnotetext{
${ }^{103}$ Yakye Axa, supra note 95, para. 146.

${ }^{104}$ Moiwana Community v. Suriname, 15 June 2005, I/A Court H.R., Judgment, para. 131.

105 Ibid, paras. 199 and 233.3.

${ }^{106}$ Saramaka, supra note 15 , para. 129.

107 Ibid., P. Nikken, 'Balancing of Human Rights and Investment Law in the Inter-American System of Human Rights', in P. Dupuy, E. Petersmann and F. Francioni (eds.), Human Rights in International Investment Law and Arbitration (Oxford University Press, Oxford, 2009) pp. 246-271.

108 Saramaka, supra note 15, para. 129.

109 Ibid.

${ }^{110}$ Ibid.

111 Ibid.

${ }^{112}$ Ibid., para. 125.
} 
'Saramakas' property rights, including their rights to natural resources found on and within the territory but only prior consent. ${ }^{113}$

In the ruling on the territories of the Kichwa Peoples of Sarayaku and the Communities of the Bobonaza River, the property awarded to the indigenous communities in 1992 was a stake due to the exploitation of oil resources. ${ }^{114}$ The question at issue regarded the control over the country's oil resources from a nationalist perspective and from a standpoint of 'national security', an economic-political concept that defined the oil sector as a strategic area. ${ }^{115}$ According to the applicants, "oil exploitation had resulted in large-scale environmental costs which included, among other matters, spills of large amounts of crude oil, contamination of water sources due to waste from hydrocarbon production (...) this environmental pollution had generated health risks for the inhabitants of the oil producing areas of eastern Ecuador". ${ }^{116}$

The contractor's obligations included preparing an EIA containing a description of the natural resources (especially the forests, wild flora and fauna) as well as of the social, economic and cultural aspects of the affected communities and drawing an Environmental Management Plan for the exploitation to preserve the existing ecological balance in the exploration area. ${ }^{117}$ The IACtHR concluded that the lack of consultation and consent had put the community's territory, life, and culture at risk.

Concerning the FPIC, the Court observed that different interpretation criteria are followed by domestic courts: "courts of countries that have not ratified C169 have also referred to the need to carry out prior consultations with indigenous, autochthonous or tribal communities regarding any administrative or legislative measure that directly affects them, as well as with regard to the exploitation of natural resources on their territory". ${ }^{118}$ Also the Court stipulated that " $[t]$ he obligation to consult the indigenous and tribal communities and peoples on any administrative or legislative measure that may affect their rights, as recognized under domestic and international law, as well as the obligation to guarantee the rights of indigenous peoples to participate in decisions on matters that concern their interests, is directly related to the general obligation to guarantee the free and full exercise of the rights recognized in the Convention (Article 1(1))". ${ }^{119}$

With regard to the relationship between IIL and FPIC, the Court clarified that the state has various obligations. First, the states' "[d]uty to organize appropriately the entire government apparatus and, in general, all the organizations (...) so that they are capable of legally guaranteeing the free and full exercise of those rights". ${ }^{120}$ Second, states are under "the obligation to structure their laws and institutions so that indigenous, autochthonous or tribal communities can be consulted effectively, in accordance with the relevant international standards". ${ }^{21}$ Third, states "must incorporate those standards into prior consultation

\footnotetext{
${ }^{113}$ Ibid., para. 127.

${ }^{114}$ Matter of Pueblo indigena de Sarayaku regarding Ecuador, 6 July 2004, I/A Court H.R., Provisional measures order (only in Spanish); Matter of Pueblo indigena de Saravaku regarding Ecuador, 6 June 2005, I/A Court H.R Provisional measures order (only in Spanish).

115 Sarayaku, supra note 27.

${ }^{116}$ Ibid.

${ }^{117}$ Ibid.

${ }^{118}$ Sarayaku. supra note 27, para. 164.

${ }^{119}$ Ibid., para. 166.

${ }^{120}$ Ibid.

${ }^{121}$ Ibid.
} 
procedures, in order to create channels for sustained, effective and reliable dialogue with the indigenous communities in consultation and participation processes through their representative institutions". ${ }^{122}$

As regards C169, the Court underlined the State's obligation to guarantee the right to consultation of the Sarayaku people. In this case, the IACtHR created a test to be applied in order to determine if there has been a proper consultation, particularly, in large projects without, however, establishing a threshold. ${ }^{123}$ First, consultation must take place in advance. ${ }^{124}$ Second, good faith should govern the process and the goal of reaching an agreement. ${ }^{125}$ Third, consultation must be organised in an adequate and accessible manner. ${ }^{126}$ Fourth, the consultation must be informed. ${ }^{127}$ For the first time in the history of the Inter-American Court's judicial practice, a delegation of judges conducted a proceeding at the site of the events of a contentious case submitted to its jurisdiction. ${ }^{128}$

More recently, in Kaliña and Lokono peoples v. Surinam the Court ruled on FPIC and indigenous peoples' right to environmental protection, mentioning the accountability of private corporations. ${ }^{129}$ The case arose out of a bauxite-mining project carried out by subsidiaries of Alcoa and BHP Billiton, without consulting the Kaliña and Lokono peoples and skipping any form of EIA. Specifically, the upshot of this case is the Court's consideration regarding FPIC and EIA. The Court determined that neither the granting of mining concessions and licenses nor the establishment and permanence to date of the nature reserves were subject to any consultation procedure aimed at obtaining the prior, free and informed consent of the Kaliña and Lokono peoples. ${ }^{130}$ The upshot of the case is that the state in question acknowledged that the "principle of free, prior and informed consent [was] an international requirement that States should adhere to when consulting indigenous and tribal people" but then it denied that there were indigenous peoples affected in the mining area. ${ }^{131}$

The Court called on the state to guarantee "the effective participation of the Kaliña and Lokono peoples should also be ensured by the State in relation to any development or investment plan, as well as any new exploration or exploitation operations that may be started up in the future in the traditional territories of these peoples". ${ }^{132}$ As for the EIA, the Court reminded that the separate state's obligation to conduct an environmental and social impact assessment performed by "independent and technically-qualified entities, under the State's supervision, have made a prior assessment of the social and environmental impact", respecting and ensuring the effective participation of the indigenous people. ${ }^{133}$ Consequently, the Court ordered Suriname to take rehabilitation measures to redress the serious damage caused by the

\footnotetext{
122 Ibid.

${ }^{123}$ Sarayaku,supra note 27, para. 50(a).

${ }^{124}$ Ibid., para. 51(b).

125 Ibid., para. 53(c).

126 Ibid., para. 57(d).

${ }^{127}$ Ibid., para. 60(B.6).

${ }^{128}$ On April 21, 2012, a delegation from the Court visited the territory of the Sarayaku People. Ibid., paras. 63(B.8) and 59 (e).

${ }^{129}$ Kaliña and Lokono Peoples v. Suriname, 25 November 2015, I/A Court H.R., Judgment.

${ }^{130}$ Ibid., para. 1.

${ }^{131}$ Ibid., paras. 204 and 205.

${ }^{132}$ Ibid., para. 211.

133 Ibid., para. 214.
} 
mining. Finally, the IACtHR referred to the responsibility of corporations vis-à-vis indigenous peoples rights highlighting that 'the mining activities that resulted in the adverse impact on the environment and, consequently, on the rights of the indigenous peoples, were carried out by private agents', and that in light of the UN Guiding Principles 'businesses must respect and protect human rights, as well as prevent, mitigate, and accept responsibility for the adverse human rights impacts directly linked to their activities". ${ }^{134}$

From this evolution in the IACtHR's jurisprudence the main conclusion that can be drawn is that the state of the art reveals an evolution in the interpretation of FPIC from the indigenous peoples' right to be consulted to a clear articulation of prior consent as a requirement. Clearly, the right to indigenous communal property and to a cultural identity are cardinal in the progress attained. Taking a revolutionary approach, the IACtHR in an evolving interpretation of $\mathrm{C} 169$ relying on the protection of communal property has drawn on this to establish customary international norms regulating FPIC based on Article 38 of the Statute of the International Court of Justice and on an examination of domestic laws adopted in several countries. ${ }^{135}$ The Court has defined the standards to be followed for the states to conduct a consultation aimed at obtaining consent, without nevertheless establishing a threshold. Environmental protection is intertwined with the safeguard of the communal indigenous property in recent cases, the Court has further emphasised that indigenous participation in the environmental and social impact assessment is mandatory but separate from prior consent. As the IACtHR stated in Sarayaku, "the right to use and enjoy the territory would be meaningless for indigenous and tribal communities if that right were not connected to the protection of natural resources in the territory". ${ }^{136}$

In terms of the shortcomings, despite the significant developments achieved, there are still pending issues. Some of them operate on a theoretical/conceptual plane and concern the interpretation of crucial legal issues. Other go beyond the legal reasoning followed by the Court and refer to the effectiveness of reparation and the implementation of the rulings.

With regard to the first set of issues, the interpretation of FPIC is partially clouded by the fact that the Court has been hesitant about defining its nature, based on self-determination and the principle of non-discrimination. This is understandable as the nature of FPIC, as an international law norm, is still unsettled in light of Article 38 of the Statute of the International Court of Justice, which identifies the sources of international law. The Court has resorted to the principles of international law (Article 38.1.c), namely the principles of good faith and nondiscrimination, with a vaguer meaning. ${ }^{137}$ Its excellent analysis of domestic legislation and case law, however, indicates that FPIC is regulated in customary international law (Article 38.b). ${ }^{138}$ The Court's rulings act as vehicles to change the present state of affairs in terms of indigenous rights, but such a judicial activism has its limitations. Just to mention a couple of them, it depends on the Court's composition, and ultimately, the positive effect depends to a certain extent on the enforcement of the judgments.

\footnotetext{
${ }^{134}$ Ibid., paras. 223 and 224.

${ }^{135}$ A. Fuentes, 'Judicial Interpretation and Indigenous Peoples' Rights to Lands, Participation and Consultation. The Inter-American Court of Human Rights', 23:1 International Journal on Minority and Group Rights (2016) pp. $39-79$.

136 Sarayaku supra note 27, para.146.

${ }^{137}$ Sarayaku supra note 27, para. 186, footnote 267 and para. 232.

${ }^{138}$ Awas Tingni supra note 90.
} 
Regarding the second set of challenges (effectiveness of reparation and implementation of rulings), clearly, the sole title does not solve the controversy since the state is the owner of the subsoil. Achieving compliance with the ruling may take a long time. To illustrate: in Awas Tingni Community, compliance with the judgment, the process of de-marking and the issuing of titles was not completed until December $2008 .{ }^{139}$ Similarly, the provision of reparation can prove to be an uphill battle as Antkowiak demonstrates in the Saramaka case, defining it as "a legal victory" with negative consequences that stemmed from "a deeper entanglement in neoliberalisms". ${ }^{140}$ The interplay with domestic courts has proved to be constructive but the Court has also encountered resistance. ${ }^{141}$

Outside the Inter-American Human Rights System ('IAHRS'), the African Commission on Human and Peoples' Rights ('ACHPR') has also referred to FPIC, although in a different legal setting. ${ }^{142}$ In the Advisory Opinion on the adoption of UNDRIP issued by the ACHPR, other points were raised for discussion. Specifically, concerning FPIC, the ACHPR observed the convergence and similarities between UNDRIP and regional law adopted by the African Union, mentioning as an example the African Convention on the Conservation of Nature and Natural Resources whose major objective is: "to harness the natural and human resources of our continent for the total advancement of our peoples in spheres of human endeavour" (preamble) and which is intended "to preserve the traditional rights and property of local communities and request the prior consent of the communities concerned in respect of all that concerns their access to and use of traditional knowledge", which is similar to the provisions of Article 10, 11(2), 28(1) and 32 of UNDRIP. ${ }^{143}$

By way of illustration, it is useful to compare this with the protection of environmental rights in the ACHPR, which has focused on the rights of indigenous peoples and tribes under the African Charter on Human Rights. ${ }^{144}$ However, the consideration of either FPIC or of a related right to consultation has not hitherto achieved a degree of protection analogous to that which it has achieved in Inter-American Human Rights law. ${ }^{145}$ The reason may be that, as Udombana recalls, "determining Africa's indigenous peoples has been largely controversial". ${ }^{146}$ The ACHPR's definition comprises "those particular groups who have been left on the margins of development and who are perceived negatively by dominating mainstream development, whose cultures and ways of life are subject to discrimination and contempt and whose existence is under threat of extinction". ${ }^{147}$

\footnotetext{
${ }^{139}$ Saramaka supra note 15.

${ }^{140}$ TM Antkowiak, 'A Dark Side of Virtue: The Inter- American Court and Reparations for Indigenous Peoples', 25:1 Duke Journal of Comparative \& International Law (2014) pp. 1-80.

${ }^{141}$ See, for instance, Colombian Constitutional Court ST-769-09.

${ }^{142}$ G. Lynch, 'Becoming Indigenous in the Pursuit of Justice: The African Commission on Human and Peoples' Rights and the Endorois', 111 (442) Afr Aff (Lond) (2012) pp. 24-45.

${ }^{143}$ Advisory Opinion on UNDRIP, African Commission, (2007), para. 35.

${ }^{144}$ See also Maya indigenous community of the Toledo District supra note 80, para. 197(1).

${ }^{145} \mathrm{~J}$. Igoe, 'Becoming indigenous peoples: Difference, inequality, and the globalization of East African identity politics', 105:420 Afr Aff (2006) pp. 399-420.

146 N. Udombana, 'Reparations and Africa's Indigenous Peoples', in F. Lenzerini (ed.), Reparations for Indigenous Peoples International and Comparative Perspectives (Oxford University Press, Oxford, 2009) pp. 389-407, p. 392.

${ }^{147}$ ACHPR, Indigenous Peoples in Africa: The Forgotten Peoples? (African Commission, Banjul, 2006), p. 11.
} 
In particular, the ACHPR has considered that the right to consultation may be seen as a "subset of the self-determination or self-management provisions of the African Charter, especially when held in the light of (...) ILO No. 169". ${ }^{148}$ Despite this affirmation, "the majority of African States remained unenthusiastic about the idea of the right to consultation". ${ }^{149}$ However, it is acknowledged that the right to consultation is particularly crucial taking into consideration that " $[\mathrm{m}]$ any indigenous Africans have been forcibly evicted or displaced due to the so-called large-scale development projects - dam building, energy projects". ${ }^{150}$ There is a narrower and indirect protection granted by national constitutions which guarantees the right to participate in governmental affairs and decision-making processes. ${ }^{151}$ In Social and Economic Rights Action Center and Center for Economic and Social Rights v. Nigeria No. 155/96, the ACHPR reaffirmed the obligation to "respect, protect, promote, and fulfil' human rights $(\ldots)$ the four levels require States to both positively and negatively adhere to these duties and can be found in the African Charter". ${ }^{152}$ In the Endorois case, concerning forcible evictions, the ACHPR examined whether the State of Kenya's creation of a 'Game Reserve', which displaced some members of the Endorois indigenous community from their ancestral land and restricted the community's access to it, was consistent with respect for the indigenous community's rights to their ancestral lands and resources. ${ }^{153}$ The ACHPR considered then issue of indigenous communities' rights to their ancestral lands and resources in the context of environmental conservation. The ACHPR explained that in these types of cases, a State's limitations on rights must be proportionate to a legitimate need and should be the least restrictive measures possible. ${ }^{154}$ The ACHPR considered that "even if the Game Reserve was a legitimate aim and served a public need, it could have been accomplished by alternative means proportionate to the need" ${ }^{155}$ It thus, concluded, that Kenya

[b]y forcing the community to live on semi-arid lands without access to medicinal salt licks and other vital resources for the health of their livestock, (...) had created a major threat to the Endorois pastoralist way of life (...) thus the very essence of the Endorois' right to culture has been denied, rendering the right, to all intents and purposes, illusory. ${ }^{156}$

Albeit not that developed as in the Inter-American System, the practice of African System demonstrates that a certain regional consensus on the application of C169 has been reached

\footnotetext{
148 J. James-Eluyode, 'The Blurred Lines: Analysing the Dynamics of States' Duty and Corporate Responsibility to Consult in Developing Countries', 23:3 African Journal of International and Comparative Law (2015) pp. 405409.

${ }^{149}$ Ibid.

${ }^{150}$ Udombana, supra note 146, p. 399.

151 James-Eluyode, supra note 148, p. 412.

${ }^{152}$ Social and Economic Rights Action Center and Center for Economic and Social Rights v. Nigeria, 27 May 2002, African Commission of Human Rights, Case No. 155/96, para. 44.

${ }^{153}$ Centre for Minority Rights Development (Kenya) and Minority Rights Group (on behalf of Endorois Welfare Council) / Kenya, 25 November 2009, African Commission of Human Rights, Case No. 276/03.

${ }^{154}$ Ibid., para. 100.

${ }^{155}$ Ibid., para. 101.

${ }^{156}$ Ibid., para. 251 (the text in italics is added).
} 
with regard to FPIC promoted at UN and ILO level, most clearly through UNDRIP which draws together the protection of specific rights of indigenous peoples in a systematic manner.

In an overall appraisal of the protection of FPIC. At the regional level, the Commission and the Court of the IAHRS have developed through case law the related rights to consultation and the protection of the environment. Particularly, they have clarified the conflicting rights involved, and identified that indigenous communities should have the right to FPIC, control over, and even in some cases consent to the development of natural resources, including the territories where these are situated. Furthermore, they should have the right to restoration of the status quo ante where harmful effects have occurred. However, there remains a long road to travel between ruling that reparation must take place, and ensuring that it is done.

The ACHPR has also recognised FPIC in discussion, but has yet to realise the extent of related protection achieved under IAHRS, because of among other things the difficulty of identifying Africa's indigenous peoples. A right to participation has however been accepted, and in some circumstances a right to consultation. The concepts of legitimate need and proportionality have also been recognised by the Commission as relevant to decision-making in cases of environmental conservation.

\subsection{Cases before International Investment Tribunals}

International investment tribunals have been confronted with cases concerning indigenous peoples' rights. Investment comes often with a downside, as corporations may engage in internationally wrongful acts, which are not (yet) considered to fall under the international responsibility regime.

International investment agreements are silent about human rights protection and do not refer to FPIC. The predominant and traditional IIL literature (with some exceptions) has tended to overlook FPIC. New approaches are clearly identifying indigenous peoples' rights as one set of the potential rights in conflict with investors' rights. ${ }^{157}$ Almost no International Investment Agreement (IIA) has laid down clauses protecting indigenous rights or articulating a preventative process to avoid harmful effects. ${ }^{158}$ The CAFTA-DR's Citizen Submission Process is one of these few agreements. ${ }^{159}$ In addition, the World Bank has attempted to draft guidelines in this regard. ${ }^{160}$ The argument a contrario sensu indicates that investors may contribute to raising the standards of protection and cooperate in demanding compliance with the FPIC legal framework.

Usually, there is a conflict between treatment standards protecting investors' rights contained in an IIA and an FPIC that is often reflected in expropriation by the host state. ${ }^{161}$

\footnotetext{
${ }^{157}$ C. Binder, 'Investment, development and indigenous people', in S. W. Schill, C. J. Tams and R. Hofmann (eds.), International Investment Law and Development: Bridging the Gap (Brill, Leiden, 2015) pp. 423-452.

${ }^{158}$ International Investment Agreement comprise international treaties of bilateral and multilateral nature that contain several clauses (standards of treatment) to protect foreign investors in the host state, contemplating also the possibility to settle the disputes before an international arbitral tribunal.

159 J. M. Balzac, 'CAFTA-DR's Citizen Submission Process: Is It Protecting the Indigenous Peoples Rights and Promoting the Three Pillars of Sustainable Development?', 11 Loy. U. Chi. Int'l L. Rev. (2013) pp. 11-63.

${ }^{160}$ M. Guidi, 'The protection of indigenous peoples' concerns in World Bank-funded projects', in G. Sacerdoti et al. (eds.), General Interests of Host States in International Investment Law (Cambridge University Press, Cambridge, 2014) pp. 237-264, pp. 238-239.

${ }^{161}$ Treatment standards include equitable treatment, full protection and security, an effective means of enforcing rights, non-arbitrary treatment, non-discriminatory treatment and national most favourable treatment.
} 
Some of these controversies have arisen in cases submitted to the International Centre for the Settlement of Investment Disputes (ICSID). ${ }^{162}$

Some investment tribunals seem to be missing the point that international investment law does not operate in a vacuum. However, FPIC has not been addressed in-depth by international investment tribunals, which have usually taken a narrow-minded legalist approach. In addition, there is no binding system of precedent in international investment arbitration. Despite these limitations, some landmark investment cases in which indigenous rights were at stake provide a fertile ground for reflection. From a conceptual standpoint, the common characteristic is the tension between a human-rights approach and the emphasis on investment protection.

In Glamis Gold Ltd v. United States (2009) the investor claimed that certain federal government actions and California measures requiring backfilling and grading for mining operations in the proximity of Quechan Native American sacred sites affecting open-pit mining were tantamount to the expropriation of the investments, in violation of Articles 1110 and 1105 of the NAFTA. ${ }^{163}$ During the government-to-government consultations with the Quechan, the parties discussed the importance of the area to the Quechan people's cultural resources and religious values as well as the religious significance of the area, which was comparable to 'Jerusalem or Mecca'. ${ }^{164}$ The Quechan argued that the US Constitution's First Amendment protected their freedom to exercise their religion. ${ }^{165}$ Thus, there was a conflict between religious rights under the First Amendment and mining rights triggered by the government's authorisation for the mining, which, according to the Quechan, "would have violated their rights under the First Amendment and destroyed their ability to practice their religion". ${ }^{166}$ The state's position was that in the event of a conflict between religious concerns and mining rights on federal lands, the Mining Law would take precedence and, therefore, the proposed project would be a valid operation.

When confronted with the question of indigenous rights, the arbitral tribunal circumscribed its decision to the main issues presented, asserting that even if the decision concerned "environmental regulation, the interests of indigenous peoples, and the tension sometimes seen between private rights in property and the need of the State to regulate the use of property (...)"; it was not required to decide many of the most controversial issues raised in the proceedings because these issues fell outside the case-specific mandate. ${ }^{167}$ Although there were amicus curiae submitted by a varied group of interested non-parties, the tribunal in its decision did not address the particular questions raised by these submissions. Ultimately, the arbitral tribunal took the view that the host state had not breached the applicable bilateral treaty and dismissed all the foreign investor's claims.

\footnotetext{
${ }^{162}$ On the origins and development of international investment law see K Miles, 'International Investment Law and Universality: Histories of Shape-Shifting', 3 Cambridge Journal of International and Comparative Law (2014) pp. 986-1100.

${ }^{163}$ Glamis Gold, Ltd. v. The United States of America, 8 June 2009, UNCITRAL. Arbitral Tribunal constituted under Chapter 11 of the North American Free Trade Agreement.

${ }^{164}$ Glamis, para. 8.

${ }^{165} \mathrm{Ibid}$., para.111.

${ }^{166}$ Ibid., para. 114

${ }^{167}$ Ibid., para. 8.
} 
Zimbabwe Border Timbers Limited and Others v. Republic of Zimbabwe were joined

\footnotetext{
${ }^{168}$ Border Timbers Limited and others v. Republic of Zimbabwe, ICSID Case No. ARB/10/25; Bernhard von Pezold and others v. Republic of Zimbabwe (ICSID Case No. ARB/10/15). Award rendered by the Tribunal on 28 July 2015.

${ }^{169}$ Ibid., paras. 97-115.

170 Ibid., para. 57.

${ }^{171}$ Burlington v. Ecuador, Burlington Resources Inc. v. Republic of Ecuador, ICSID Case No. ARB/08/5. 172 Ibid.

${ }^{173}$ M. Krajewski, Ensuring the Primacy of Human Rights in Trade and Investment Policies: Model clauses for a UN Treaty on transnational corporations, other businesses and human rights (CIDSE, Brussels, 2017) pp. 9-19. ${ }^{174}$ Anaya and Puig, supra note 33, p. 3.
} 
human rights in IIL. Krajweski points at the fact that "potential conflicts between trade and investment policies and human rights obligations (...) could be avoided or solved if human rights would always have a higher rank". ${ }^{175}$ Although de lege lata "there is no clear and coherent practice establishing hierarchy in favour of human rights obligations", the IACtHR has drawn a sort informal hierarchy, as reflected in Sawhoyamaxa. ${ }^{176}$

The open question is how to accommodate FPIC in investment arbitration. There are various possible avenues. First, a realistic option would be via the legal framework applicable to regulate investments, comprising both domestic law and international law. As regards national law, it is settled in IIL that only investments made in accordance to the host state's legislation (which comprises not only the provisions regulating on foreign investment but also all the relevant provisions applicable) ${ }^{177}$ enjoy protection under the respective IIA. ${ }^{178}$ Compliance with domestic law regulating consultation and FPIC thus would constitute a requirement for the investment to be lawful, which failure may give rise to a claim of illegality against the foreign investor. ${ }^{179}$ International investment arbitration practice relating to corruption cases that supports this arguments. ${ }^{180}$ In relation to the international law framework, the applicable law defined in the IIA includes international law as a whole and based on Article 31.3.c) of the $\operatorname{VCLT}^{181}$ investment tribunal could take into consideration IHRL. ${ }^{182}$ Assuming that FPIC is regulated in customary international law, as discussed above, it would become immediately applicable.

Second, there are different procedural channels to introduce FPIC as a substantive law issue to be addressed by the investment tribunal. In IIL, recently adopted procedural rules on transparency regulate third party intervention, granting the possibility to submit amicus curiae files. This procedural dimension of FPIC is analysed in detail below.

Overall, arbitral tribunals are less prone to investigate human rights or environmental damage allegations when it comes to indigenous rights. The main reason behind this reluctance is that human rights considerations are neither regulated in IIAs nor comprised within the arbitrators' mandate. In general, they circumscribe the scope of their analysis, limiting it to the claims contained in the pleadings. Hence, as it stands, the international investment system is not an adequate judicial resource to protect communal property rights of indigenous communities, right to consultation and FPIC.

\footnotetext{
175 Krajewski, supra note 173 , p. 13.

${ }^{176}$ Sawhoyamaxa, supra note 92, para.140.

${ }^{177}$ R Dolzer and C Schreuer, Principles of International Investment Law (Oxford University Press, Oxford, 2008) p. 65 .

${ }^{178}$ On illegal investments, see S. Schill, 'Illegal Investments in Investment Treaty Arbitration', 11:2 The Law \& Practice of International Courts and Tribunals (2012) pp. 281 - 323.

${ }^{179}$ D. Zachary, 'The Plea of Illegality in Investment Treaty Arbitration', 29:1 ICSID Review 2014, pp. 155-186. ${ }^{180}$ Ibid. The author examines in detail the practice of arbitral tribunals dealing with illegal investments, at 180185. One of the leading cases in this field is Inceysa Vallisoletana SL v. Republic of El Salvador, ICSID Case No ARB/03/26, Award (2 August 2006) paras. 155, 258-64. See M. Waibel et al., Conclusions, in The Backlash against Investment Arbitration: Perceptions and Reality (Kluwer International Law, Dordrecht, 2010) p. 313.

${ }^{181}$ This provision reads: 'There shall be taken into account, together with the context: (c) Any relevant rules of international law applicable in the relations between the parties'.

${ }^{182}$ B. Simma, 'Foreign Investment Arbitration: A Place for Human Rights?', 60 ICLQ (2011) pp. 573 and 584.
} 


\section{Discussion: Two Sides of the Same Coin?}

The analysis here of the key case law in these two regions (namely Latin America and Africa) allows us to examine the question of the nature of FPIC as well as to reflect on the obstacles experienced in its implementation. FPIC is multifaceted and its implementation involves both procedural and substantive aspects. The set of principles that together can achieve its successful implementation must be drawn from several distinct areas of law and formulated as fundamental rights and procedural rules which underpin FPIC.

The cases previously examined are complex and constitute notable examples of fragmentation between different areas of international law. Article 31 (3) c of the VCLT presents an invaluable tool for the integration of international law in international judicial decision-making as it claims that treaty provisions should not be interpreted in isolation. ${ }^{183}$ Applying or ignoring certain norms has practical consequences for different legal sub-systems, risking different results. Namely, a contextual interpretation would help in reconciling or bridging the various areas of international law. Nevertheless, the reservations expressed by international courts and tribunals in opening up a self-contained regime (be that IHRL or IIL) may thwart this aim.

Amongst international case law and different theoretical foundations that have contributed to shape FPIC, IHRL is central. FPIC is a human right rooted in and heavily reliant on other rights mainly, self-determination as a founding principle of indigenous peoples' rights and the right to cultural identity. From a strictly legal and de lege lata standpoint, there is a consensus on FPIC which is reflected in the different rulings that apply the norms guaranteeing such rights.

As occurs in other areas of international law, implementation gaps remain. Scholars such as Rodríguez-Garavito, Schilling-Vacaflor and Grugel have provided a more interdisciplinary analysis identifying the contradictions and weaknesses of protection afforded in state practice. Referring to the application of C169 in the Andean region, they have recognised "ambiguous effects on indigenous peoples' rights and environmental justice". ${ }^{184}$ According to Rodríguez-Garavito there are different interpretations of FPIC that can be observed in state practice, which vary from essentially weak to strong interpretations of C169. ${ }^{185}$ Problems arising from the implementation of the right to consultation are noticeable, as Schilling-Vacaflor and Gruegel have demonstrated in their respective studies of the several consultations that have taken place in Bolivia in the hydrocarbon sector. ${ }^{186}$ Both studies have pinpointed serious shortcomings in consultation practices. ${ }^{187}$ Schilling-Vacaflor, in particular, alludes to the "information hurdle" and other "irregularities, the limited decision-making power of affected local populations and the lack of transparency regarding the compensation payments". ${ }^{188}$

\footnotetext{
${ }^{183}$ Ibid.

${ }^{184}$ Rodríguez-Garavito, supra note 16, pp. 1-44.

${ }^{185}$ Ibid., p. 27.

${ }^{186}$ A Schilling-Vacaflor and R Flemmer, Why is Prior Consultation Not Yet an Effective Tool for Conflict Resolution? The Case of Peru, Working Paper No 220 (April 2013)

187 A Schilling-Vacaflor, 'Prior Consultations in Plurinational Bolivia: Democracy, Rights and Real Life Experiences', 8:2 Latin American and Caribbean Ethnic Studies (2013) pp. 202-220.

188 Ibid., pp. 202-203.
} 
Thus, one might argue de lege ferenda that the present legal understanding of FPIC should be reformulated and understood as a stand-alone principle or second-order right. The underpinning argument for such a stance is the acknowledgement of the current limits of its interpretation and the need to secure protection other than that obtained under existing human rights systems. Taking into consideration the implementation deficit stemming from the cases we have seen above; a more realistic approach seems to be in order. This approach would set out more clearly and more extensively the body of principles and procedural rules which together would promote an effective formulation of FPIC, capable of being applied throughout the various arenas where indigenous peoples have sought to assert it, which range from the familiar setting of human rights courts to the less obvious but nonetheless crucial setting of international investment tribunals.

A shift in this regard in theory and law could be observed in an attempt to accommodate the protection of indigenous peoples' rights particularly, the right to property, in the framework of IIL. ${ }^{189}$ From a theoretical viewpoint, Hirsch puts forward a more reasonable approach to the question from the perspective of the sociology of international law, analysing the socio-legal elements involved in the relations between HRL and IIL. ${ }^{190}$ In an attempt to change the current regulatory framework, Krajweski advocates for the introduction of human rights model clauses in future IIAs: supremacy clause guaranteeing the prevalence of human rights provisions (with different formulations), a clause ensuring the observance of human rights in dispute settlement proceedings and a clause incorporating human rights obligations. ${ }^{191}$

A joint analysis of the cases reveals some key procedural aspects of particular interest for an effective implementation of FPIC. First, access to justice in IIL relates to a more general and fundamental principle, which is the rule of law. In other words, the "[i]mpartial protection by independent judges of equal rights of citizens (...) and the 'rule of law' (...) is increasingly recognized in constitutional law and HRL as a human right". ${ }^{192}$ Certainly, there are disparities in the access to justice because indigenous communities have only limited international legal standing. To make matters even more complicated, international litigation may be scattered across jurisdictions and across normally unconnected areas of law. FPIC cases are highly complex and concern not only legal disputes, but often environmental conflicts which go beyond law. A lengthy process and a lack of legal standing may end up eroding indigenous peoples and environmental rights.

Second, the timing and the uniqueness of the consultation determine the effectiveness of the process. Procedurally, timing is everything when it comes to FPIC. The consultation should be organised before the relevant investment or infrastructure project takes place and it

\footnotetext{
${ }^{189}$ F. Baetens, Investment Law within International Law (Cambridge University Press, Cambridge, 2013); E. De Brabandere and T. Gazzini (eds.), International Investment Law. The Sources of Rights and Obligations (Martinus Nijhoff Publisher, Leiden, 2012); M. Krepchev, 'The Problem of Accommodating Indigenous Land Rights in International Investment Law', 6 J Int. Disp. Settlement (2015), pp. $42-73$.

${ }^{190}$ M. Hirsch, Invitation to the Sociology of International Law (Cambridge University Press, Cambridge, 2015). See Chapter 5, where Hirsch discusses 'Socio-Legal Fragmentation, Investment Tribunals and Human Rights Law', in particular p. 136.

${ }^{191}$ Krajewski, supra note 173, pp. 20-29.

${ }^{192}$ E. Petersmann, 'Why Justice and Human Rights Require Cosmopolitan International Economic Law', in F. Lenzerini and A. Vrdoljak (ed.), International Law for Common Goods: Normative Perspectives on Human Rights, Culture and Nature (Hart Publishing, Portland, 2014) pp. 117-135, p. 121.
} 
substantially differs from the EIA. The 'post' consultation is not effective, as it may not prevent environmental damages in indigenous lands from happening. ${ }^{193}$

Third, as for the amicus curiae briefs, following the tendency to guarantee more transparency in IIL, indigenous peoples can file amicus curiae briefs as a new channel for their voice to be heard in investment cases. ${ }^{194}$ Nevertheless, the effect can be limited as the submissions cannot alter or affect the parties' rights and the arbitral tribunal shall decide what arguments it takes on board. ${ }^{195}$ Yet, in any case, there is no acknowledgement of violation of rights or award of compensation for damages.

Fourth, concerning the petitions before human rights regional bodies, at least in Latin America the filing of applications to the Commission (and eventually taking the case to the Court) appears to be the main procedural channel when it comes to the violation of FPIC. Obviously, the UN mechanisms are used in a complementary manner. As a significant development, in Africa the role of the Commission has increased in recent years covering relevant issues relating to the implementation of FPIC.

Fifth, and with regard to other possible procedural tools that may contribute to the protection of FPIC, one can mention the adoption of precautionary or provisional measures where those are available. ${ }^{196}$ This is the only means within the international dimension to avoid a worsening of the situation, which may render the outcome of the ruling illusory. Petitioners, victims and their counsels should be aware and active to request the adoption of such measures.

Additionally, there are other measures for protecting both indigenous people and their environment that can be effectively used by international bodies, such as expert witnesses, onsite visits and specialised studies and reports. As a further step to effectively understand the context of the case, reliance on expert witnesses (anthropologists or historians) may help to develop an authentic dialogue with another system of social and legal norms. Another innovative measure adopted by the IACtHR consists of in loco visits. Finally, the adoption of specialised reports is contributing a great deal in this respect as they raise awareness about the current situation of indigenous peoples and increasing pressure on the States to comply with international law. The possibility of articulating restorative measures could be used in negotiations to enhance the bargaining power of indigenous peoples. These strategies increase the transaction costs that weaker parties have to pay to engage in arbitration proceedings to form a coalition that could more effectively bargain with their more powerful counterparts.

In sum, international human rights instruments reflect consensus towards the recognition of FPIC as a right. No state would formally oppose to UNDRIP. In an overall appraisal of the current state practice and case law, one can observe a gradually, albeit slowly, opening-up in the practice of international courts and tribunals to customary law. There is

\footnotetext{
${ }^{193}$ For instance, the contested construction of a highway through the Isiboro Sécure National Park and Indigenous Territory (Territorio Indígena y Parque Nacional Isiboro Secure-TIPNIS) has received a lot of attention. However, there was not initial consultation. Only after a series of demonstrations, the government first, decided to cancel the project to then rectify and organise a consultation which outcome was approval of the project by the majority of the communities involved.

${ }^{194}$ ICSID Rules were reformed in 2006. UNCITRAL adopted Transparency Rules in 2014. The United Nations Convention on Transparency in Treaty-based Investor-State Arbitration (the so-called 'Mauritius Convention on Transparency') was adopted on 10 December 2014.

${ }^{195}$ H. Yu and M.B. Olmos Giupponi, 'The Pandora Box Effects under the UNCITRAL Transparency Rules', 5 Journal of Business Law (2016) pp. 347-372.

${ }^{196}$ For instance, in the Inter-American System of Human Rights, according the Court's procedural rules.
} 
however an extensive archipelago of narrowly focused and poorly coordinated international law norms. The need to devise effective means to guarantee FPIC is still there. At the minimum, a clear understanding of the right, a permanent oversight and access to legal advice by indigenous communities are sorely needed.

\section{Conclusions}

While at present the formulation of FPIC seems to have gained momentum in terms of legal instruments which regulate the process, both its implementation in traditional fora and the attempts to assert it in new arenas such as investment law have revealed several obstacles such as: the lack of a homogeneous approach, the confusion between different procedural aspects, the delayed response to the breach of the right and the inappropriate timing to conduct the consultation.

Due to the changing face of international law and the increasing role of non-state actors, the irruption of private corporations acting in the field has made matters even more complex. International law cannot remain aloof from this phenomenon. Indeed, effectiveness is at the centre of the problem.

The jurisprudence of the IACtHR has paved the way for the safeguard of FPIC and related rights, and has harnessed its evolution. However, one should be aware of the limitations of the 'expansive effect' of C169. The IACtHR has construed the notion of indigenous rights linking them to the right to property, interpreted in a cultural context, being the delimitation and restitution of the property in the common manner of reparation. The IACtHR has been reluctant to provide a general response: it follows a case-by-case analysis and it has clearly stated that it cannot adjudicate disputes between private parties such as those in Sawhoyamaxa Community.

Investment tribunals have taken a distinctive look at the issue of consultation, but as yet have been hesitant to accommodate FPIC in the framework of investment protection. Conceiving of FPIC more broadly as the apex of a panoply of fundamental rights and procedural rules would enable a core set of qualities to be identified. Some of these could then be defined expressly as aspects of FPIC in argument before investment tribunals, as a means of creating a link from the narrow interpretative context of investment law more effectively to a legal formulation of the broader needs of indigenous peoples. The efforts made in the context of specific disputes demonstrate that the responsibility to fulfil FPIC rests with the host state, but the foreign investor should respect FPIC and observe the national and international legal framework applicable to regulate the investment.

Although several unresolved questions persist, a light at the end of the tunnel may be seen as certain progress has been achieved. As argued in the article, we may extract certain common elements from the litigation before human rights courts and investment tribunals as discussed in the previous section. An alternative formulation of FPIC militates for the recognition of its sui generis nature rooted in human rights law but yet comprising specific obligations stemming from customary international law. 